\title{
Thermo-oxidative decomposition behavior of starch-g-poly(citronellyl methacrylate) and starch-g-poly(citronellyl acrylate) copolymers
}

\author{
Marta Worzakowska ${ }^{1}$
}

Received: 30 September 2017 / Accepted: 19 December 2017 / Published online: 2 January 2018

(c) The Author(s) 2018. This article is an open access publication

\begin{abstract}
The paper describes the studies on the thermo-oxidative decomposition behavior of two types of starch graft copolymers: starch-g-poly(citronellyl acrylate) copolymers with the grafting percent $(\% \mathrm{G}): 21.3 \% \pm 0.5,35.8 \% \pm 0.6$ and $59.8 \% \pm 0.3$ and starch-g-poly(citronellyl methacrylate) copolymers with $\% \mathrm{G}: 21.3 \% \pm 0.4,37.0 \% \pm 0.2$ and $51.8 \% \pm 0.3$ prepared applying the "grafting from" method. The decomposition course of copolymers by using the TG/ DTG/DSC/FTIR analysis was evaluated. As it was found, the course of TG/DTG/DSC curves was independent on the \%G but it was directly dependent on the type of analyzed copolymer. It resulted in completely different decomposition course of starch-g-poly(citronellyl acrylate) copolymers under the presence of oxidative conditions as compared to starch-gpoly(citronellyl methacrylate) copolymers. Thanks to applying the FTIR analysis of the gaseous products emitted under the heating of the studied materials, the detailed decomposition course of copolymers was evaluated.
\end{abstract}

Keywords Starch · Copolymers - Citronellyl acrylate - Citronellyl methacrylate $\cdot$ Thermal behavior

\section{Introduction}

Starch is an environmentally friendly, carbohydrate, macromolecular compound which finds it applications in many field of industry such as a food, pharmaceutical, medicine and paper industries. According to the literature survey, the decomposition mechanism of this natural polymer under various environments, artificial and natural, is widely studied and discussed. Generally, different, simultaneous phase transformations under the heating of starch happen. The most significant of all are melting, evaporation, sublimation, chemical condensation, decomposition and carbonization leading to the creation of the mixture of volatiles [1-6]. Due to the availability of starch, its low cost and the presence of hydroxyl groups in its structure, it can be chemically modified and thus different structure starch graft copolymers with potential applications as fillers, stabilizers, impact resistant materials,

Marta Worzakowska

marta.worzakowska@poczta.umcs.lublin.pl

1 Faculty of Chemistry, Department of Polymer Chemistry, Maria Curie-Skłodowska University, Gliniana 33 Street, 20-614 Lublin, Poland plastics, modifiers, matrices, excipients, etc., can be prepared. Among them, the thermal properties of starch graft copolymers obtained using different structure methacrylate and acrylate monomers have been widely studied [7-21]. Recently, at the Department of Polymer Chemistry UMCS, the intensive studies on the synthesis, physicochemical properties and thermal behavior of novel, non-described in the literature data, starch-g-copolymers are conducted. To this time, we succeed in the preparation the starch-gcopolymers based on aromatic methacrylate and acrylate monomers such as phenyl and benzyl meth(acrylates). The studies of their properties affirmed that the decomposition course of those copolymers is complex and leads to the formation of the mixture of volatile products and covered series, simultaneous processes [22-26]. Due to the fact that those copolymers were characterized by promising physicochemical properties and thermal stability which acted them as attractive materials for the preparation of more environmentally friendly products which could replace petrochemical plastics, we decided to continue our studies on the chemical modification of starch by other methacrylate and acrylate monomers. Lately, applying the monomers prepared from methacryloyl or acryloyl chloride and natural terpene alcohol: citronellol allowed obtaining 
amphiphilic starch-g-copolymers with excellent chemical resistance toward acidic, neutral and buffer environment, high moisture resistance, which were resistant to polar and nonpolar solvents with satisfactory thermal properties under inert atmosphere. However, most of the materials are processed and manufactured in the presence of air, so the thermal properties of novel materials under oxidative conditions are of high importance on account of their practical utilization. And thus, the present paper describes the thermal properties and the studies on the evaluation of decomposition course of two types of novel materials: starch-g-poly(citronellyl methacrylate) and starch-gpoly(citronellyl acrylate) copolymers which differ in their grafting percent $(\% \mathrm{G})$. The influence of copolymer structure on the course of their degradation under the heating in the presence of oxidative conditions has been evaluated.

\section{Materials}

To the present studies, the series of copolymers which differ in their grafting percent $(\% \mathrm{G})$ were chosen, as shown in Table 1 . The copolymers were obtained according to the methodology described in Refs. [24, 26, 27]. Generally, the graft copolymerization conditions are placed in Table 1.

Copolymer $1-{ }^{13} \mathrm{C} / \mathrm{CP}$ MAS NMR $(75.5 \mathrm{MHz}, \delta$ ppm) 174.8 $(\mathrm{C}=\mathrm{O}), 81.1,93.5,101.8(\mathrm{CH}-\mathrm{O}), 72.6(\mathrm{C}-\mathrm{O}), 61.5\left(\mathrm{CH}_{2}-\right.$ O), 20.0, 25.8, 30.3, $37.5\left(\mathrm{CH}_{3}, \mathrm{CH}_{2}, \mathrm{CH}\right)$; FTIR (thin film, $\left.\mathrm{cm}^{-1}\right): 3336(\mathrm{v} \mathrm{OH}), 2866,2922,2945$ (v C-H), 1728 (v $\mathrm{C}=\mathrm{O}), 1375,1448(\delta \mathrm{C}-\mathrm{H}), 1018,1076,1150$ (v C-O), 758, 839, $928(\mathrm{v}=\mathrm{C}-\mathrm{H})$.
Copolymer $2-{ }^{13} \mathrm{C} / \mathrm{CP}$ MAS NMR (75.5 MHz, $\delta$ ppm) 174.9 $(\mathrm{C}=\mathrm{O}), 81.2,93.5,101.7(\mathrm{CH}-\mathrm{O}), 72.6(\mathrm{C}-\mathrm{O}), 61.6\left(\mathrm{CH}_{2}-\right.$ O), 20.1, 25.8, 30.1, $37.7\left(\mathrm{CH}_{3}, \mathrm{CH}_{2}, \mathrm{CH}\right)$; FTIR (thin film, $\left.\mathrm{cm}^{-1}\right)$ : 3338 ( $(\mathrm{OH}), 2867,2920,2947(v \mathrm{C}-\mathrm{H}), 1728(\mathrm{v}$ $\mathrm{C}=\mathrm{O}), 1377,1448(\delta \mathrm{C}-\mathrm{H}), 1018,1074,1150(v \mathrm{C}-\mathrm{O})$, 760, 838, 929 ( $v=\mathrm{C}-\mathrm{H})$.

Copolymer $\quad 3-{ }^{13} \mathrm{C} / \mathrm{CP} \quad$ MAS NMR $\quad(75.5 \mathrm{MHz}, \delta$ ppm) $\quad: 174.8(\mathrm{C}=\mathrm{O}), 81.1,93.7,101.5(\mathrm{CH}-\mathrm{O}), 72.5(\mathrm{C}-$ O), $61.6\left(\mathrm{CH}_{2}-\mathrm{O}\right), 20.1,25.6,30.0,37.8\left(\mathrm{CH}_{3}, \mathrm{CH}_{2}, \mathrm{CH}\right)$; FTIR (thin film, $\left.\mathrm{cm}^{-1}\right): 3338(\mathrm{v} \mathrm{OH}), 2865,2921,2947(\mathrm{v}$ $\mathrm{C}-\mathrm{H}), 1728$ ( $v \mathrm{C}=\mathrm{O}), 1378,1445(\delta \mathrm{C}-\mathrm{H}), 1018,1074$, $1152(v \mathrm{C}-\mathrm{O}), 758,838,930(\mathrm{v}=\mathrm{C}-\mathrm{H})$.

Copolymer $4-{ }^{13} \mathrm{C} / \mathrm{CP}$ MAS NMR (75.5 MHz, $\delta$ ppm) 176.8 $(\mathrm{C}=\mathrm{O}), 81.3,93.3,102.0(\mathrm{CH}-\mathrm{O}), 72.6(\mathrm{C}-\mathrm{O}), 61.3\left(\mathrm{CH}_{2}-\right.$ O), 19.9, 25.7, 30.4, 37.5, $45.1\left(\mathrm{CH}_{3}, \mathrm{CH}_{2}, \mathrm{CH}\right)$; FTIR (thin film, $\left.\mathrm{cm}^{-1}\right)$ : $3320(\mathrm{v} \mathrm{OH}), 2865,2950(\mathrm{v} \mathrm{C}-\mathrm{H}), 1726$ (v $\mathrm{C}=\mathrm{O}), 1370,1445(\delta \mathrm{C}-\mathrm{H}), 997,1014,1076,1145(v \mathrm{C}-$ O), 748, 840, $927(\mathrm{v}=\mathrm{C}-\mathrm{H})$.

Copolymer $\quad 5-{ }^{13} \mathrm{C} / \mathrm{CP} \quad$ MAS NMR $\quad(75.5 \mathrm{MHz}, \delta$ ppm) :176.8 (C=O), 81.2, 93.3, $102.1(\mathrm{CH}-\mathrm{O}), 72.6(\mathrm{C}-$ O), $61.4\left(\mathrm{CH}_{2}-\mathrm{O}\right), 19.9,25.8,30.5,37.5,45.0\left(\mathrm{CH}_{3}, \mathrm{CH}_{2}\right.$, $\mathrm{CH})$; FTIR (thin film, $\left.\mathrm{cm}^{-1}\right): 3322(\mathrm{v} \mathrm{OH}), 2867,2950(\mathrm{v}$ $\mathrm{C}-\mathrm{H}), 1726(\vee \mathrm{C}=\mathrm{O}), 1368,1445(\delta \mathrm{C}-\mathrm{H}), 998,1015$, 1076, 1147 (v C-O), 748, 842, $927(v=\mathrm{C}-\mathrm{H})$.

Copolymer $6-{ }^{13} \mathrm{C} / \mathrm{CP}$ MAS NMR (75.5 MHz, $\delta$ ppm) 176.6 $(\mathrm{C}=\mathrm{O}), 81.3,93.1,101.9(\mathrm{CH}-\mathrm{O}), 72.6(\mathrm{C}-\mathrm{O}), 61.1\left(\mathrm{CH}_{2}-\right.$ O), 19.8, 25.5, 30.4, 37.2, $45.1\left(\mathrm{CH}_{3}, \mathrm{CH}_{2}, \mathrm{CH}\right)$; FTIR (thin film, $\left.\mathrm{cm}^{-1}\right)$ : 3324 ( $\left.\mathrm{v} \mathrm{OH}\right), 2865,2952$ (v C-H), $1726(\mathrm{v}$ $\mathrm{C}=\mathrm{O}), 1370,1447(\delta \mathrm{C}-\mathrm{H}), 998,1014,10767,1147(\mathrm{v} \mathrm{C}-$ O), 749, 840, 925 (v=C-H).

Table 1 Graft copolymerization reaction conditions

\begin{tabular}{|c|c|c|c|c|c|c|c|}
\hline Sample & $\begin{array}{l}\text { Starch/ } \\
\mathrm{g}\end{array}$ & $\begin{array}{l}\text { Citronellyl } \\
\text { acrylate/g }\end{array}$ & $\begin{array}{l}\text { Citronellyl } \\
\text { methacrylate/g }\end{array}$ & $\begin{array}{l}\text { Initiator } \\
(\mathrm{K} 2 \mathrm{~S} 2 \mathrm{O} 8) / \mathrm{g}\end{array}$ & $\begin{array}{l}\text { Reaction temp./ } \\
{ }^{\circ} \mathrm{C}\end{array}$ & $\begin{array}{l}\text { Reaction time/ } \\
\text { min }\end{array}$ & $\% \mathrm{G}$ \\
\hline $\begin{array}{l}\text { Copolymer } \\
1\end{array}$ & 2.5 & 0.625 & - & 0.0625 & 80 & 90 & $21.3 \pm 0.5$ \\
\hline $\begin{array}{l}\text { Copolymer } \\
2\end{array}$ & 2.5 & 1.875 & - & 0.0875 & 80 & 90 & $35.8 \pm 0.6$ \\
\hline $\begin{array}{l}\text { Copolymer } \\
3\end{array}$ & 2.5 & 3.125 & - & 0.1125 & 80 & 90 & $59.8 \pm 0.3$ \\
\hline $\begin{array}{l}\text { Copolymer } \\
4\end{array}$ & 2.5 & - & 1.875 & 0.0875 & 80 & 120 & $21.3 \pm 0.4$ \\
\hline $\begin{array}{l}\text { Copolymer } \\
5\end{array}$ & 2.5 & - & 3.750 & 0.1250 & 80 & 120 & $37.0 \pm 0.2$ \\
\hline $\begin{array}{l}\text { Copolymer } \\
6\end{array}$ & 2.5 & - & 5.000 & 0.1500 & 80 & 120 & $51.8 \pm 0.3$ \\
\hline
\end{tabular}

The structure of the obtained materials was confirmed based on spectroscopic analyses 


\section{Methodology}

Thermo-oxidative behavior of starch-g-poly(citronellyl acrylate) and starch-g-poly(citronellyl methacrylate) copolymers was studied using a STA 449 F1 Jupiter Netzsch instrument (Germany) linked online with a FTIR gas analyzer Bruker Tensor 27, TGA 585 (Germany). Simultaneous, TG/DTG/DSC studies in $\mathrm{Al}_{2} \mathrm{O}_{3}$ crucibles using sensor thermocouple type $\mathrm{S}$ TG-DSC, at the temperature range of $40-700{ }^{\circ} \mathrm{C}$ with sample mass ca. $10 \mathrm{mg}$ and with a heating rate of $10{ }^{\circ} \mathrm{C} \mathrm{min}^{-1}$ were performed. The synthetic air with a flow rate of $100 \mathrm{~mL} \mathrm{~min}{ }^{-1}$ was applied as a furnace atmosphere. The gaseous FTIR spectra in the range from 600 to $4000 \mathrm{~cm}^{-1}$ with a resolution of $4 \mathrm{~cm}^{-1}$ were collected over the whole analysis time.

\section{Results and discussion}

\section{Starch-g-poly(citronellyl acrylate) copolymers}

Figure 1 presents the TG, DTG and DSC curves achieved under the heating of starch-g-poly(citronellyl acrylate) copolymers. As it is clearly visible, the course of the presented curves is very similar and it is independent on $\% \mathrm{G}$ of copolymers. Generally, on TG/DTG curves, three main temperature ranges where the changes in mass loss are indicated. The first mass loss $\left(\Delta m_{1}\right)$ from 2.5 to $4.7 \%$ at the temperatures up to ca. $170{ }^{\circ} \mathrm{C}$ and with $T_{\max 1}$ ca. $89-96{ }^{\circ} \mathrm{C}$ was observed, as shown in Table 2. In addition, when one have a look at the DSC curves, one can see only one endothermic peak at this temperature range. Analyzing the gaseous FTIR results, gathered at $T_{\max 1}$, the presence of the absorption signals responsible for the water vapor (bands at the wavelength of approx. 1400-1800 and $3500-3900 \mathrm{~cm}^{-1}$ ) was indicated, as shown in Fig. 2. So, the results confirmed that this stage was not connected with the degradation of copolymers but only with the physical transformation (water evaporation from the samples which was absorbed under the synthesis of copolymers and the sample storage).

The second mass loss $\left(\Delta m_{2}\right)$ happens between the temperatures ca. $170-440{ }^{\circ} \mathrm{C}$. It is worth noticing that this stage is composed at least with two, non-well-separated stages. It indicates on the complex course of the studied samples. Commonly, the mass loss in this stage is comparable for all the studied copolymers and amounts ca. $65.6-66.5 \%$. In addition, the first one stage was described by high intensity DTG peak with the rate of the transformation ca. $11.9-12.7 \% \mathrm{~min}^{-1}$ and DTG peak temperature at ca. $284-286{ }^{\circ} \mathrm{C}$, as shown in Table 2 . However, the second one is characterized by low-intensity DTG peak
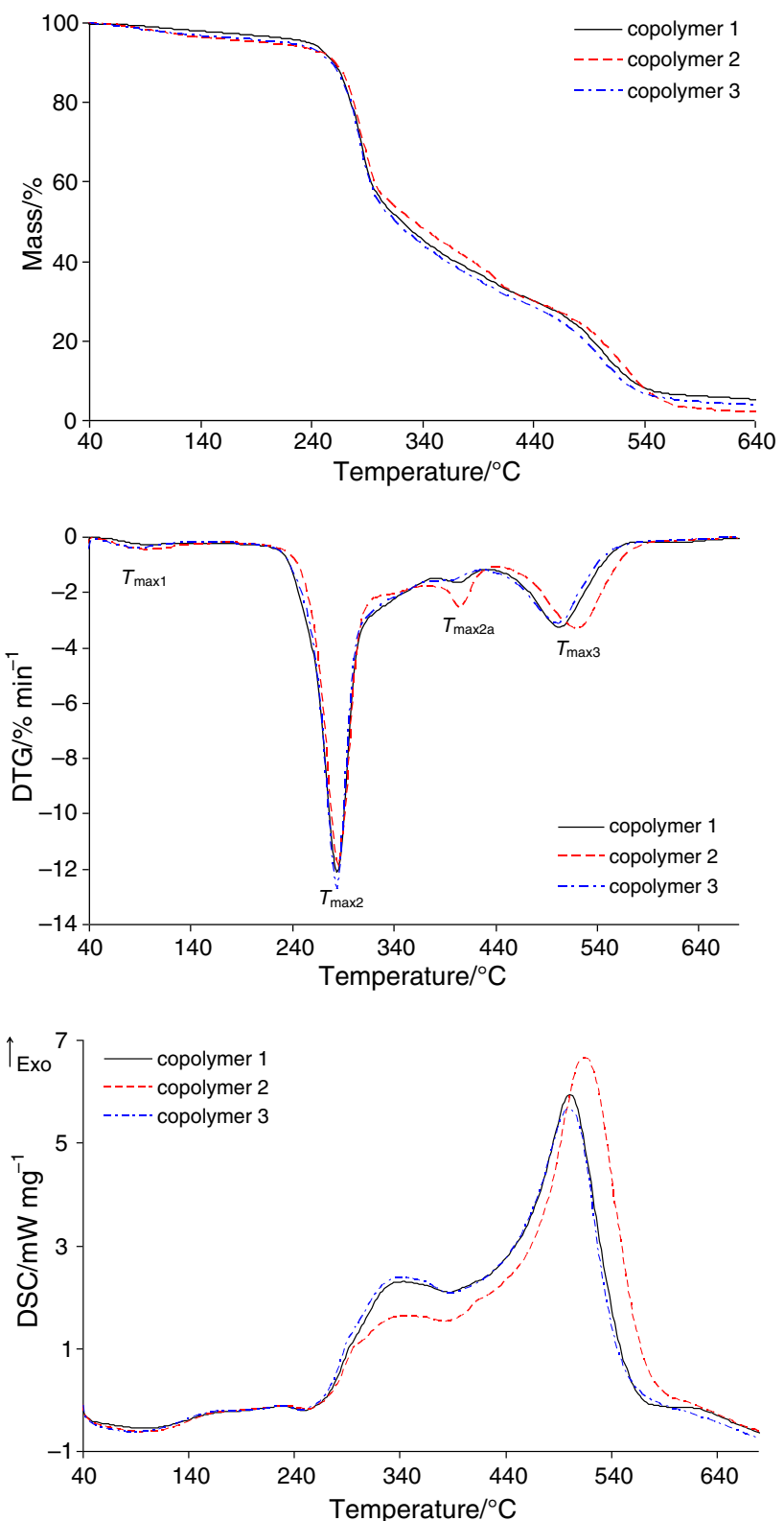

Fig. 1 TG, DTG and DSC curves for starch-g-poly(citronellyl acrylate) copolymers in air

with the rate of the transformation ca. $1.5-2.5 \% \mathrm{~min}^{-1}$ and similar $T_{\max 2 \mathrm{a}}\left(399-405^{\circ} \mathrm{C}\right)$. Comparing the DSC curves, its similar course was also observed at these temperature ranges. Only, exothermic signals which were likely due to the oxidation decomposition processes of the studied materials were appeared. The FTIR spectrum of the gases extracted at $T_{\max 2}$ is a typical gases spectrum for starch decomposition products in oxidative conditions, which is in agreement with the literature data [1-6]. However, on the FTIR spectrum gathered at $T_{\max 2 \mathrm{a}}$, one can see mainly the emission of $\mathrm{CO}_{2}$ (bands at the wavelength of approx. 670 and $2330-2365 \mathrm{~cm}^{-1}$ ), $\mathrm{CO}$ (bands at the wavelength of 
Table 2 TG/DTG data for the starch-g-poly(citronellyl acrylate) copolymers in air

\begin{tabular}{llllllll}
\hline Sample & $T_{\max 1} /{ }^{\circ} \mathrm{C}$ & $\Delta_{\mathrm{m} 1} / \%$ & $T_{\max 2} / T_{\max 2 \mathrm{a}} /{ }^{\circ} \mathrm{C}$ & $\Delta_{\mathrm{m} 2} / \%$ & $T_{\max 3} /{ }^{\circ} \mathrm{C}$ & $\Delta_{\mathrm{m} 3} / \%$ & $\mathrm{rm} / \%$ \\
\hline Copolymer 1 & 96 & 2.5 & $284 / 401$ & 66.2 & 502 & 26.2 & 5.1 \\
Copolymer 2 & 94 & 4.7 & $286 / 405$ & 65.6 & 520 & 28.1 & 1.6 \\
Copolymer 3 & 89 & 4.1 & $284 / 399$ & 66.5 & 503 & 26.1 & 3.3 \\
\hline
\end{tabular}

$r m$ residual mass at $700{ }^{\circ} \mathrm{C}$
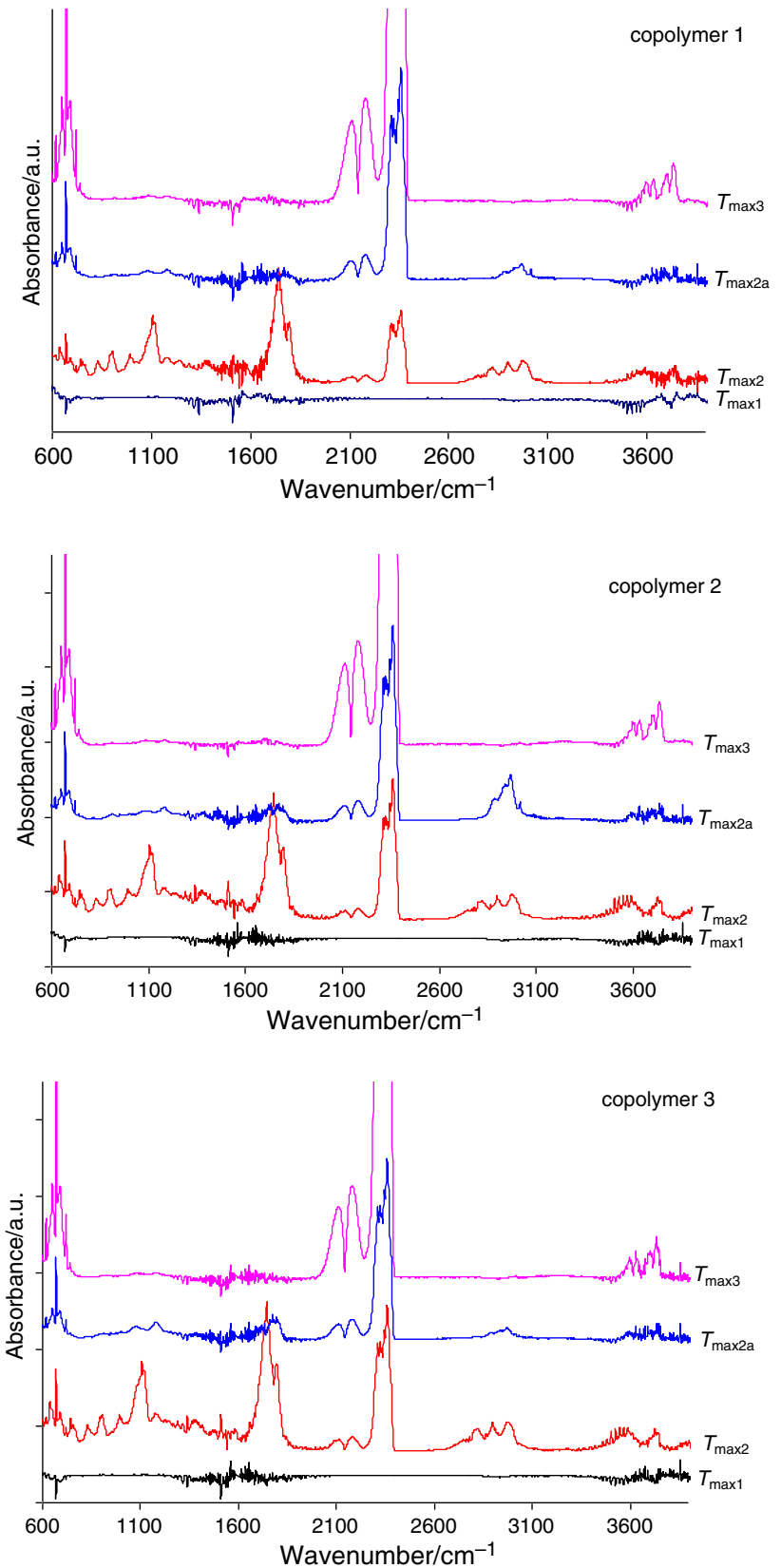

Fig. 2 Gaseous FTIR spectra for the studied starch-g-poly(citronellyl acrylate) copolymers in air

approx. 2000 and $2200 \mathrm{~cm}^{-1}$ ), $\mathrm{H}_{2} \mathrm{O}$ (bands at the wavelength of approx. $3500-3900 \mathrm{~cm}^{-1}$ ), $\mathrm{CH}_{4}$ (band at the wavelength of approx. $3014 \mathrm{~cm}^{-1}$ ) and small amounts of other organic gaseous products. Among them, it can be suspected the occurrence of some species having aliphatic structure which is confirmed by the presence of the bands at the wavelengths at the range of $2860-2960 \mathrm{~cm}^{-1}$ corresponding to the stretching vibrations of $\mathrm{C}-\mathrm{H}$ and lowintensity bands at the wavelengths of $1380-1460 \mathrm{~cm}^{-1}$ responsible for the deformation vibrations of $\mathrm{C}-\mathrm{H}$. Besides those signals, on the FTIR spectrum, small-intensity absorption signal at the wavelength of approx. $3050 \mathrm{~cm}^{-1}$ connected with the stretching vibrations of $=\mathrm{C}-\mathrm{H}$ and the signals at $900-980 \mathrm{~cm}^{-1}$ which are due to the out-of-plane deformation vibrations could testify to the emission of some alkene species. Unfortunately, the stretching bands of $\mathrm{C}=\mathrm{C}$ were unseen from the spectra. It could be due to the emission of water vapor which masks the $\mathrm{C}=\mathrm{C}$ bands. (As it is visible, the water bands give jagged spectra.) Under this decomposition stage, also the absorption bands responsible for the stretching vibrations of $\mathrm{C}-\mathrm{O}$ (1060-1168 $\left.\mathrm{cm}^{-1}\right)$, for the stretching vibrations of $\mathrm{C}=\mathrm{O}$ (ca. $1172 \mathrm{~cm}^{-1}$ ) and the stretching vibrations of $\mathrm{C}-\mathrm{H}$ in aldehyde group (ca. $2720 \mathrm{~cm}^{-1}$ ) are clearly appeared [28, 29]. It indicates on the emission of some organics having oxygen in their structure. Taking into account the structure of obtained copolymers and the FTIR results it can be concluded that at temperatures above $300{ }^{\circ} \mathrm{C}$, the decomposition of copolymers assumes a number of simultaneous reactions. Among them, main and side chains scissors, decarboxylation, dehydration and oxidation processes were the most expected. It led to the formation of alkanes, alkenes and aldehydes as main volatile products, as it was shown in Scheme 1.

Finally, third main decomposition stage between the temperatures from ca. $440{ }^{\circ} \mathrm{C}$ to ca. $680{ }^{\circ} \mathrm{C}$ with $T_{\max 3}$ at 502-520 ${ }^{\circ} \mathrm{C}$ and similar mass loss (26-28\%) was appeared. The DTG peak with intermediate decomposition rate (3.0-3.2\% $\mathrm{min}^{-1}$ ) was detected. At this temperature range, one, broad exothermic signal was visible from DSC curves which suggested the oxidation processes of formed residues. It was confirmed based on the FTIR results where only the emission of inorganic species such as $\mathrm{CO}_{2}, \mathrm{CO}$ and $\mathrm{H}_{2} \mathrm{O}$ was detected (Table 2). 
Scheme 1 The main decomposition products of starch-g-poly(citronellyl acrylate) copolymers at $T_{\max 2 a}$

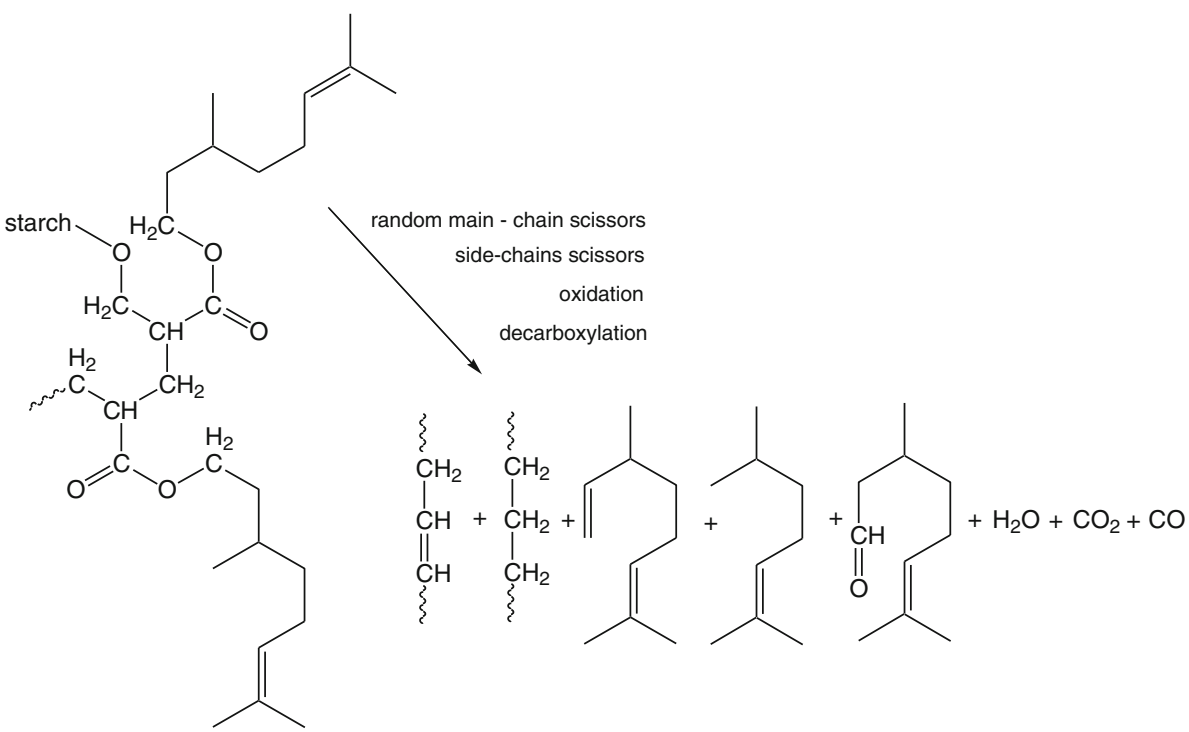

Table 3 TG/DTG data for starch-g-poly(citronellyl methacrylate) copolymers in air

\begin{tabular}{|c|c|c|c|c|c|c|c|c|c|}
\hline Sample & $T_{\max 1} /{ }^{\circ} \mathrm{C}$ & $\Delta_{\mathrm{m} 1} / \%$ & $T_{\max 2} /{ }^{\circ} \mathrm{C}$ & $\Delta_{\mathrm{m} 2} / \%$ & $T_{\max 3} / T_{\max 3 \mathrm{a}} / T_{\max 3 \mathrm{~b}} /{ }^{\circ} \mathrm{C}$ & $\Delta_{\mathrm{m} 3 /} \Delta_{\mathrm{m} 3 \mathrm{a}}+\Delta_{\mathrm{m} 3 \mathrm{~b}} / \%$ & $T_{\max 4} /{ }^{\circ} \mathrm{C}$ & $\Delta_{\mathrm{m} 4} / \%$ & $\mathrm{rm} / \%$ \\
\hline Copolymer 4 & 105 & 2.3 & 186 & 5.8 & $281 / 335 / 390$ & $37.9 / 22.5$ & 555 & 29.5 & 2.0 \\
\hline Copolymer 5 & 92 & 1.7 & 177 & 9.1 & $277 / 322 / 393$ & $32.5 / 31.0$ & 553 & 24.4 & 1.3 \\
\hline Copolymer 6 & 76 & 2.3 & 172 & 8.2 & 277/323/391 & $35.2 / 33.0$ & 533 & 21.2 & 0.1 \\
\hline
\end{tabular}

$r m$ residual mass at $700{ }^{\circ} \mathrm{C}$

\section{Starch-g-poly(citronellyl methacrylate) copolymers}

On the thermogravimetric curves, four main temperature ranges where the mass loss of the copolymers under the heating in oxidative atmosphere were observed, as shown in Fig. 3. The first stage was connected with the physical transformation: evaporation of moisture from the copolymers, as it was confirmed based on the gaseous FTIR spectra recorded at $T_{\max 1}$, as shown in Fig. 4.

Between the temperatures of $150-210{ }^{\circ} \mathrm{C}$ and $T_{\max 2}$ from 172 to $186{ }^{\circ} \mathrm{C}$, the copolymers start to decompose, Table 3. The mass loss is small, and it does not exceed $10 \%$. In addition, on DTG curves low-intensity peaks with the rate of the transformation ca. $1.2-2.0 \% \mathrm{~min}^{-1}$ were appeared. The presence of this signal was unexpected since the decomposition of starch and poly(citronellyl methacrylate) polymer happened at relatively higher temperatures [6, 27, 31]. However, analyzing the gaseous FTIR spectra gathered at $T_{\max 2}$, the appearance of the bands characteristic for the stretching vibrations of $\mathrm{C}-\mathrm{H}$ at $2827-2977 \mathrm{~cm}^{-1}$, the stretching vibrations of $=\mathrm{C}-\mathrm{H}$ at $3068 \mathrm{~cm}^{-1}$, the stretching vibrations of $\mathrm{C}=\mathrm{O}$ at $1700-1790 \mathrm{~cm}^{-1}$, the deformation vibrations of $\mathrm{C}-\mathrm{H}$ at
$1344-1470 \mathrm{~cm}^{-1}$, the stretching vibrations of $\mathrm{C}-\mathrm{O}$ at $1066-1203 \mathrm{~cm}^{-1}$ and the deformation vibrations of $=\mathrm{C}-\mathrm{H}$ below $900 \mathrm{~cm}^{-1}[28,29]$ may indicate on the emission of some fragments from poly(citronellyl methacrylate) as a result of the depolymerization process initiated at the end polymer chains and further oxidation of the emitted species. What is interesting, on the DSC curves, the exothermic signals with $T_{\max }$ ca. $166-172{ }^{\circ} \mathrm{C}$ are observed which is the confirmation that under this decomposition step some of the oxidation processes happen.

The further heating of the copolymers caused their subsequent decomposition and the creation of some other volatiles. The next decomposition stage was visible from the temperature of ca. $210^{\circ} \mathrm{C}$ up to the temperature of ca. $430-450{ }^{\circ} \mathrm{C}$, and it was composed of at least three stages named as $T_{\max 3}, T_{\max 3 a} T_{\max 3 \mathrm{~b}}$. The mass loss was similar to all the studied methacrylate copolymers and amounted ca. 60-68\%. Dividing this decomposition stage onto two stages: first from the temperature of ca. $210{ }^{\circ} \mathrm{C}$ to $315^{\circ} \mathrm{C}$ $\left(T_{\max 3}\right)$ and the second from $315{ }^{\circ} \mathrm{C}$ to $430-450{ }^{\circ} \mathrm{C}\left(T_{\max 3 a}\right.$ and $T_{\max 3 \mathrm{~b}}$ ) allowed us more accurately evaluating the decomposition course of the copolymers. The mass loss between the temperatures of $210-315{ }^{\circ} \mathrm{C}$ was from 32 to $38 \%$. On the gaseous FTIR spectra collected at this 

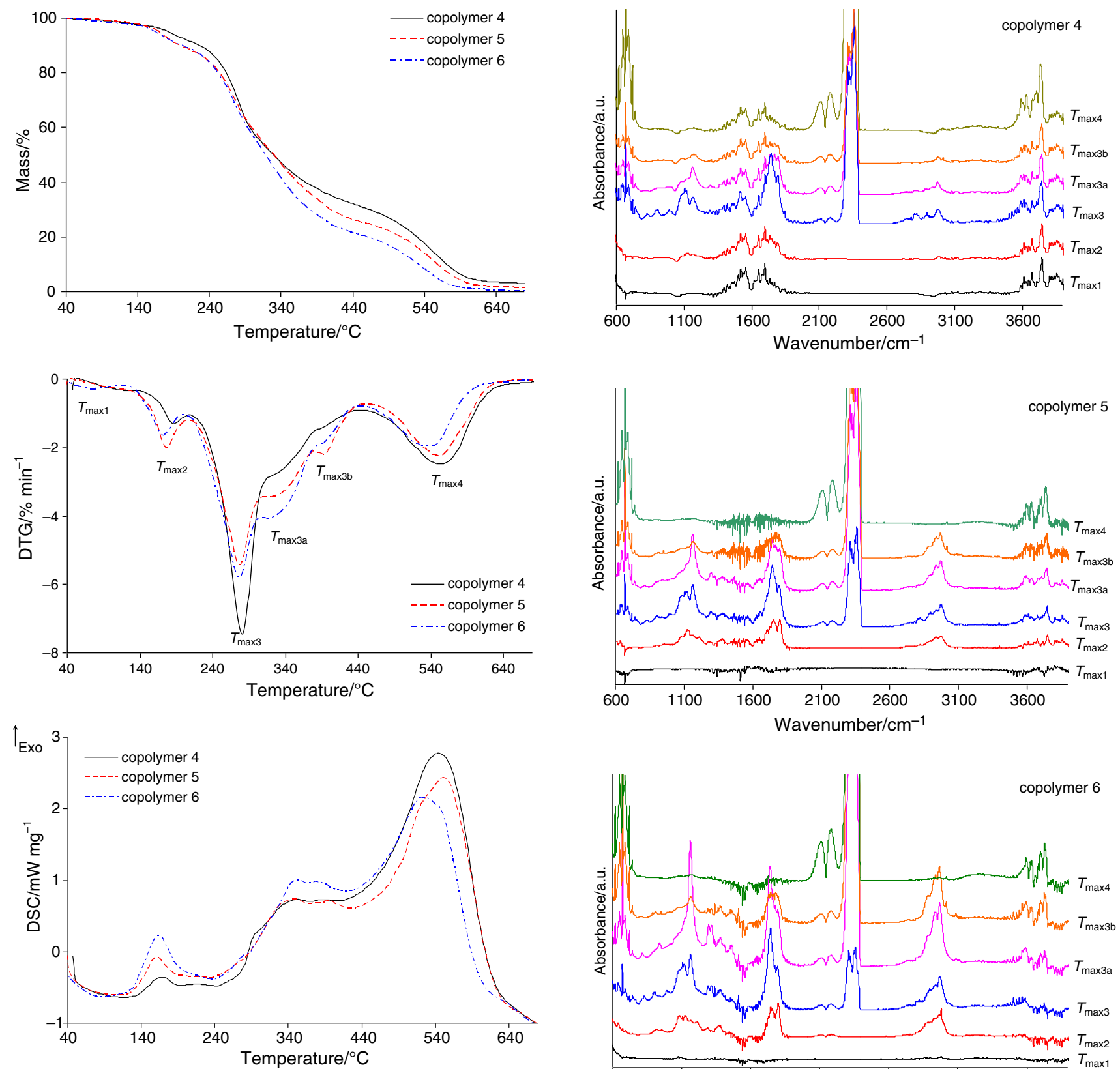

Fig. 3 TG, DTG and DSC curves for the starch-g-poly(citronellyl methacrylate) copolymers in air

temperature range, the presence of the following absorption bands: for water vapor above $3500 \mathrm{~cm}^{-1}$, for $\mathrm{CO}_{2}$ at $670 \mathrm{~cm}^{-1}$ and at $2300-2352 \mathrm{~cm}^{-1}$, for CO at $2000-2200 \mathrm{~cm}^{-1}$, for aldehydes (the stretching vibrations of $\mathrm{C}-\mathrm{H}$ at 2720 and at $2800 \mathrm{~cm}^{-1}$, the stretching vibrations for $\mathrm{C}=\mathrm{O}$ at $1735-1743 \mathrm{~cm}^{-1}$ ), for acids (the stretching vibrations of $\mathrm{C}-\mathrm{O}$ at $1250-1300 \mathrm{~cm}^{-1}$ and the stretching vibrations of $\mathrm{C}=\mathrm{O}$ at $1770-1795 \mathrm{~cm}^{-1}$ ), for furanes (the stretching vibrations of $\mathrm{C}=\mathrm{C}$ at $1510-1540 \mathrm{~cm}^{-1}$ and the out-of-plane deformation vibrations of $\mathrm{C}=\mathrm{C}$ at $820-970 \mathrm{~cm}^{-1}$ ) and for aliphatic species (the stretching

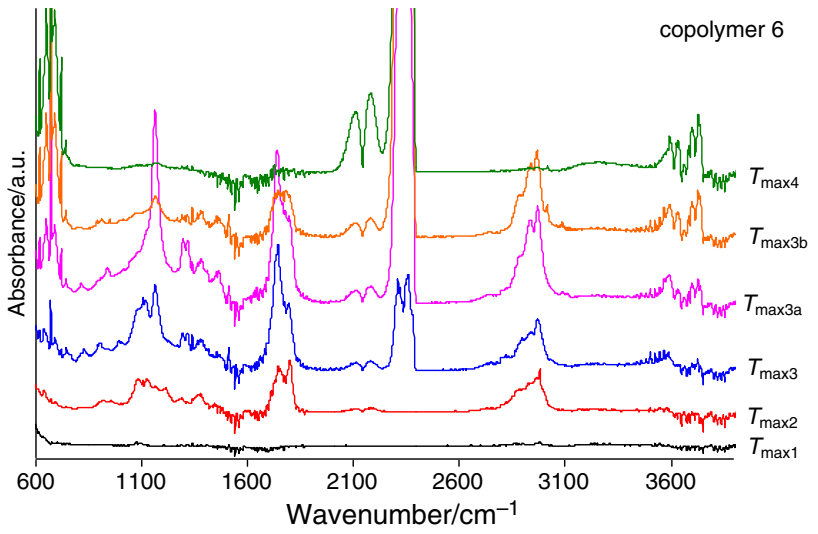

Fig. 4 Gaseous FTIR spectra for the studied starch-g-poly(citronellyl methacrylate) copolymers in air

vibrations of $\mathrm{C}-\mathrm{H}$ at $2875-2974 \mathrm{~cm}^{-1}$ and the deformation vibrations of $\mathrm{C}-\mathrm{H}$ below $900 \mathrm{~cm}^{-1}$ ) was indicated [28, 29]. The type of the emitted gaseous species proved the decomposition of starch from the copolymers at this stage and the partial oxidation processes of some gaseous decomposition products created under the heating of starch $[1-6,30,31]$. The oxidation processes were confirmed based on DSC analysis where only the exothermic signals between the temperatures of $210-315^{\circ} \mathrm{C}$ were observed. 
Scheme 2 The main decomposition products of starch-g-poly(citronellyl methacrylate) copolymers at $T_{\max 3 \mathrm{a}}$ and $T_{\max 3 \mathrm{~b}}$

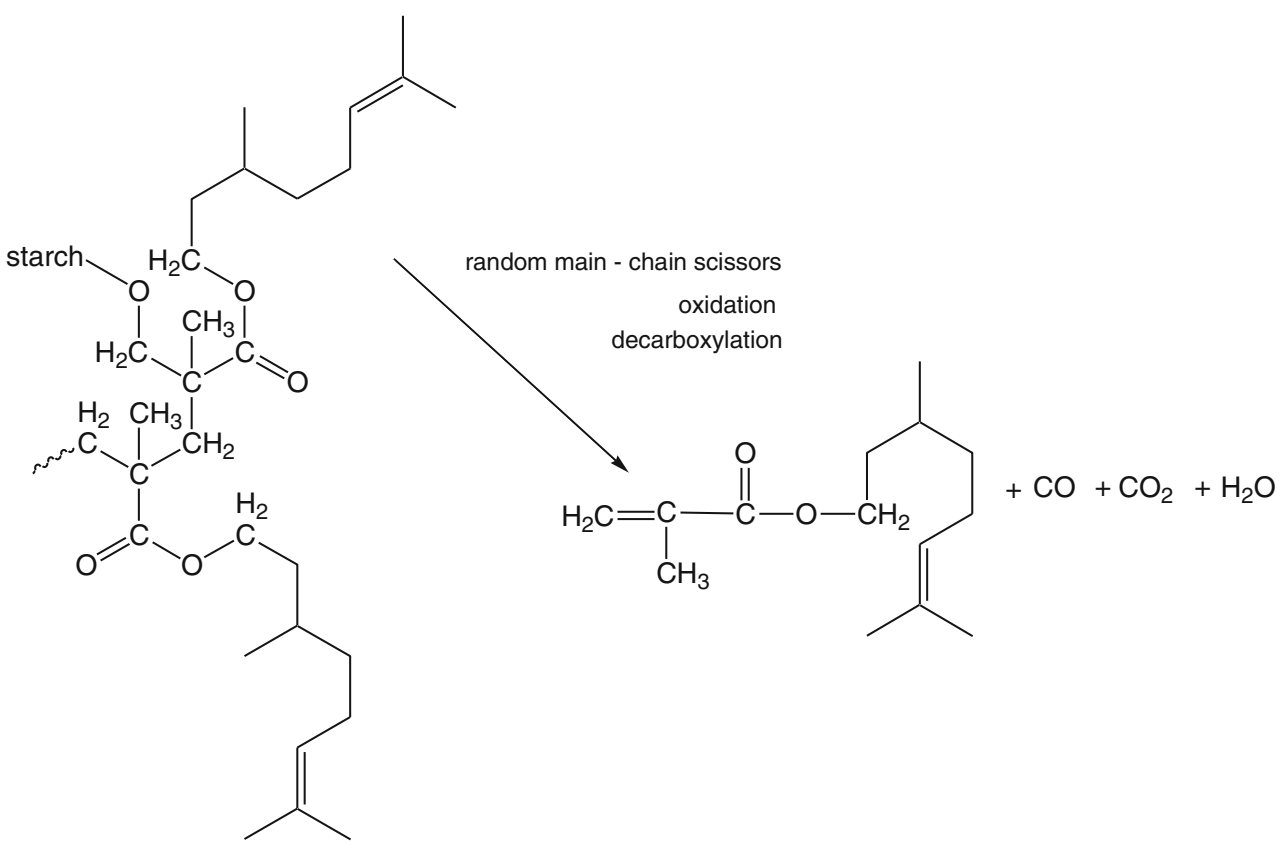

In turn, the mass loss in the next temperature range where double, non-well-separated DTG peaks were observed was from 22.5 to $33 \%$. Moreover, at this temperature range, the presence of exothermic signals on the DSC curves was confirmed, as shown in Fig. 3. What is interesting, the FTIR spectra extracted at $T_{\max 3 \mathrm{a}}$ and $T_{\max 3 \mathrm{~b}}$ have a similar course. It may testify to the creation of similar volatile products and thus on the decomposition of the same part of copolymer. Looking at the FTIR spectra collected at $T_{\max 3 \mathrm{a}}$ and $T_{\max 3 \mathrm{~b}}$, one can see the appearance of the signals responsible for the stretching vibrations of $=\mathrm{C}-\mathrm{H}\left(3083 \mathrm{~cm}^{-1}\right)$, the stretching vibrations of $\mathrm{C}-\mathrm{H}$ (2873-2990 $\left.\mathrm{cm}^{-1}\right)$, the stretching vibrations of $\mathrm{C}=\mathrm{O}$ (1735-1790 $\mathrm{cm}^{-1}$ ), the deformation vibrations of $\mathrm{C}-\mathrm{H}$ (1360-1450 $\left.\mathrm{cm}^{-1}\right)$, the stretching vibrations of $\mathrm{C}-\mathrm{O}$ (1039-1290 $\left.\mathrm{cm}^{-1}\right)$, the out-of-plane deformation vibrations of $=\mathrm{C}-\mathrm{H}\left(800-908 \mathrm{~cm}^{-1}\right)$ and the bands characteristic for $\mathrm{CO}_{2}, \mathrm{CO}$ and $\mathrm{H}_{2} \mathrm{O}$. Additionally, at $T_{\max 3 \mathrm{~b}}$, the emission of some $\mathrm{CH}_{4}$ was confirmed based on the occurrence of the absorption bands at $3014 \mathrm{~cm}^{-1}$. Although absorption signals at similar wavelengths on the FTIR spectra for starch-g-poly(citronellyl methacrylate) at $T_{\max 3 \mathrm{a}}$ and $T_{\max 3 \mathrm{~b}}$, as shown in Fig. 4 , and for starch-gpoly(citronellyl acrylate) at $T_{\max 2 a}$, as shown in Fig. 3, were visible, the appearance of the FTIR spectra for starchg-poly(citronellyl methacrylate) copolymers was quite different. It could indicate on the creation of completely different structure decomposition species under the heating of copolymers 4-6. Also, the exothermic effect at this temperature range is characterized by lower intensity for starch-g-poly(citronellyl methacrylate) copolymers as compared with starch-g-poly(citronellyl acrylate) copolymers, which could be due to the creation of volatiles which are resistant to oxidation, as shown in Figs. 1, 3. Analyzing the obtained results, we could suspect the depolymerization process of poly(citronellyl methacrylate) chains and the creation of citronellyl methacrylate monomer as a main decomposition product at temperatures above $315-320{ }^{\circ} \mathrm{C}$, besides the formation of inorganic species which are due to the decarboxylation and oxidation processes, Scheme 2.

The last decomposition stage above the temperature of $430-450{ }^{\circ} \mathrm{C}$ with $T_{\max 4} 533-555^{\circ} \mathrm{C}$ and the mass loss ranges from 29.5 to $21.2 \%$ was observed. DTG curves indicated on low-intensity peaks with the rate of the transformation ca. $3.1-3.3 \% \mathrm{~min}^{-1}$. Moreover, huge, exothermic signals on DSC curves at $T_{\max }$ ca. $524-556{ }^{\circ} \mathrm{C}$ were visible. Under this decomposition stage, the emission of $\mathrm{CO}_{2}, \mathrm{CO}$ and $\mathrm{H}_{2} \mathrm{O}$ as main volatile products was the confirmation of the oxidation processes of the formed residues.

\section{Conclusions}

Generally, based on the presented results, the course of thermogravimetric and calorimetrical curves and the position and type of absorption bands responsible for the emission of gaseous decomposition products had a similar appearance for copolymers independently on their $\% \mathrm{G}$. However, the thermal resistance, decomposition course and the type of volatiles were directly dependent on the type of the studied copolymers. 
Comparing the TG/DTG/DSC/FTIR results, it was found completely different decomposition course of starchg-poly(citronellyl acrylate) copolymers than starch-gpoly(citronellyl methacrylate) copolymers under air conditions.

Starch-g-poly(citronellyl acrylate) copolymers started to decompose at ca. $200-210{ }^{\circ} \mathrm{C}$ which was evaluated based on the $5 \%$ of mass loss. Its decomposition runs in two main stages visible at the temperature ranges from ca. $170-440{ }^{\circ} \mathrm{C}$ to $\mathrm{ca} .440-680{ }^{\circ} \mathrm{C}$. According to the gaseous FTIR results, main decomposition volatiles, besides the gaseous products characteristic for the oxidative decomposition of starch, were $\mathrm{CO}_{2}, \mathrm{CO}, \mathrm{H}_{2} \mathrm{O}$, alkane, alkene and aldehyde fragments. It indicated on the random main and side chains scissors, decarboxylation and oxidation of poly(citronellyl acrylate) chains and oxidation of formed residues.

The beginning of the decomposition of starch-gpoly(citronellyl methacrylate) copolymers at ca. $160-170{ }^{\circ} \mathrm{C}$ was observed. Its decomposition by three main stages at the temperature ranges of ca. $150-210^{\circ} \mathrm{C}$, ca. $210-430-450{ }^{\circ} \mathrm{C}$ and ca. $440-680{ }^{\circ} \mathrm{C}$ was characterized. As it was confirmed based on spectroscopic data, main decomposition products, besides the volatiles created from starch, were citronellyl methacrylate, $\mathrm{CO}_{2}, \mathrm{CO}$ and $\mathrm{H}_{2} \mathrm{O}$ which were due to the depolymerization of poly(citronellyl methacrylate), decarboxylation and oxidation of formed species and residues.

Open Access This article is distributed under the terms of the Creative Commons Attribution 4.0 International License (http://creative commons.org/licenses/by/4.0/), which permits unrestricted use, distribution, and reproduction in any medium, provided you give appropriate credit to the original author(s) and the source, provide a link to the Creative Commons license, and indicate if changes were made.

\section{References}

1. Golon A, González FJ, Dávalos JZ, Kuhnert N. Investigating the thermal decomposition of starch and cellulose in model systems and toasted bread using domino tandem mass spectrometry. J Agric Food Chem. 2013;61:674-84.

2. Haslam M. The decomposition of starch grains in soils: implications for archaeological residue analyses. J Archaeol Sci. 2004;31:1715-34.

3. Liu X, Wang Y, Yu L, Tong Z, Chen L, Liu H, Li X. Thermal degradation and stability of starch under different processing conditions. Starch-Starke. 2013;65:48-60.

4. Zhang X, Golding J, Burgar H. Thermal decomposition chemistry of starch studied by ${ }^{13} \mathrm{C}$ high-resolution solid-state NMR spectroscopy. Polymer. 2002;43:5791-6.

5. Liu X, Yu L, Xie F, Li M, Chen L, Li X. Kinetics and mechanism of thermal decomposition of cornstarches with different amylose/ amylopectin ratios. Starch-Starke. 2010;62:139-46.

6. Pielichowski K, Njuguna J. Thermal degradation of polymeric materials. Rapra technology limited 2005, UK.
7. Çankaya N. Synthesis of graft copolymers onto starch and its semiconducting properties. Results Phys. 2016;6:538-42.

8. Jyothi AN, Carvalho AJF. Starch-g-copolymers: synthesis, properties and applications. In: Kalia S, Sabaa MW, editors. Polysaccharide based graft copolymers. Berlin: Springer; 2013. p. 59-109.

9. Kaur I, Sharma M. Synthesis and characterization of graft copolymers of Sago starch and acrylic acid. Starch-Starke. 2012;64:441-51.

10. Athawale VD, Lele V. Thermal studies on granular maize starch and its graft copolymers with vinyl monomers. Starch-Starke. 2000;52:205-13.

11. Eutamene M, Benbakhti A, Khojda M, Jada A. Preparation and aqueous properties of starch-grafted polyacrylamide copolymers. Starch-Starke. 2009;61:81-91.

12. Parvathy PC, Jyothi AN. Rheological and thermal properties of saponified cassava starch-g-poly(acrylamide) superabsorbent polymers varying in grafting parameters and absorbency. J Appl Polym Sci. 2014;131:40368.

13. Kaur J, Kaith BS, Jindal R. Evaluation of physio-chemical and thermal properties of Soy protein concentrate and different binary mixtures based graft copolymers. Int $\mathrm{J}$ Sci Eng Res. 2013;4:573-9.

14. Lu DR, Xiao CM, Xu SJ. Starch-based completely biodegradable polymer materials. eXPRESS Polym Lett. 2009;3:366-75.

15. Wanga S, Xua J, Wanga Q, Fana X, Yua Y, Wanga P, Zhanga Y, Yuana J, Cavaco-Paulob A. Preparation and rheological properties of starch-g-poly(butylacrylate) catalyzed by horseradish peroxidase. Process Biochem. 2017;59:104-10.

16. Kweon DK, Cha DS, Park HJ, Lim ST. Starch-g-polycaprolactone copolymerization using diisocyanate intermediates and thermal characteristics of the copolymers. J Appl Polym Sci. 2000;78:986-93.

17. Ali FM, Farhan MA. Synthesis of substituted starch grafted methyl nadic anhydride as drug copolymer. Eur J Pharm Med Res. 2017;4:81-8.

18. Fares MM, El-faqeeh AS, Ghanem H, Osman ME, Hassan EA. Hydrogels of starch-g-(tert-butylacrylate) and starch-g-(n-butylacrylate) copolymers. J Therm Anal Calorim. 2010;99:659-66.

19. Garcia MC, Ribeiro KO, Ribeiro AEC, Caliari M. Morphological characteristics and physicochemical properties of the coproducts from wet milling of waxy maize starch. J Therm Anal Calorim. 2017. https://doi.org/10.1007/s10973-017-6254-z.

20. Tudorachi N, Chiriac AP, Nita LE, Mustata F, Diaconu A, Balan V, Rusu A, Lisa G. Studies on the nanocomposites based on carboxymethyl starch-g-lactic acid-co-glycolic acid copolymer and magnetite. J Therm Anal Calorim. 2017. https://doi.org/10. 1007/s10973-017-6682-9.

21. Beninca C, Colman TAD, Lacerda LG, da Silva Carvalho Filho MA, Demiate IM, Bannach G, Schnitzle E. Thermal, rheological, and structural behaviors of natural and modified cassava starch granules, with sodium hypochlorite solutions. J Therm Anal Calorim. 2013;111:2217-22.

22. Worzakowska M, Torres-Garcia E, Grochowicz M. Kinetics of the oxidative decomposition of potato-starch-g-poly(phenyl methacrylate) copolymers. Polym Degrad Stabil. 2015;120:384-91.

23. Worzakowska M, Torres-Garcia E, Grochowicz M. Degradation kinetics of starch-g-poly(phenyl methacrylate) copolymers. Thermochim Acta. 2015;619:8-15.

24. Worzakowska M. Starch-g-poly(benzyl methacrylate) copolymers. Characterization and thermal properties. J Therm Anal Calorim. 2016;124:1309-18.

25. Worzakowska M. Thermal behavior, decomposition mechanism and some physicochemical properties of starch-g-poly(benzyl acrylate) copolymers. J Therm Anal Calorim. 2016;126:531-40. 
26. Worzakowska M. The effect of starch-g-copolymers structure on the oxidative behavior studied by TG/DSC/FTIR-coupled method. J Therm Anal Calorim. 2017;129:367-76.

27. Worzakowska M. Chemical modification of potato starch by graft copolymerization with citronellyl methacrylate. J Polym Environ. 2017. https://doi.org/10.1007/s10924-017-1062-x.

28. Sokrates G. Infrared and Raman characteristic group frequencies, tables and charts. New York: Wiley; 2001.
29. NIST Chemistry Webbook, NIST standard reference data 2011, http://webbook.nist.gov.

30. França Lemos PV, Barbosa LS, Ramos IG, Coelho RE, Druzian JI. The important role of crystallinity and amylose ratio in thermal stability of starches. J Therm Anal Calorim. 2017. https://doi. org/10.1007/s10973-017-6834-y.

31. Liu X, Ma H, Long Y, Ling C, Zhen T, Pei C. Thermal-oxidative degradation of high-amylose corn starch. J Therm Anal Calorim. 2014;115:659-65. 